This is an electronic reprint of the original article. This reprint may differ from the original in pagination and typographic detail.

Author(s): Lillie, Nathan

Title: $\quad$ The Right Not to Have Rights: Posted Worker Acquiescence and the European Union Labor Rights Framework

Year: $\quad 2016$

Version:

Please cite the original version:

Lillie, N. (2016). The Right Not to Have Rights: Posted Worker Acquiescence and the European Union Labor Rights Framework. Theoretical Inquiries in Law, 17(1), 39-62. https://doi.org/10.1515/til-2016-0003

All material supplied via JYX is protected by copyright and other intellectual property rights, and duplication or sale of all or part of any of the repository collections is not permitted, except that material may be duplicated by you for your research use or educational purposes in electronic or print form. You must obtain permission for any other use. Electronic or print copies may not be offered, whether for sale or otherwise to anyone who is not an authorised user. 


\title{
The Right Not to Have Rights: Posted Worker Acquiescence and the European Union Labor Rights Framework
}

\begin{abstract}
Nathan Lillie*
The emergence of the European Union citizenship agenda has mainly taken place along the evolution of mobility rights, with the goal of creating a pan-European labor market. Mobility undermines the nationally embedded notion of industrial citizenship. Industrial citizenship protects workers' rights and secures their participation in national political systems. The Europeanization of labor markets severs the relationship between state, territory and citizen on which industrial citizenship has been built, undermining worker collectivism and access to representation. This is legitimated in terms of building market-citizenship, i.e., enabling mobile workers as market actors. However, the way mobility is regulated in the EU has the purpose and effect of weakening collective labor institutions, which also undermines workers 'ability to act as autonomous market actors. The same factors which undermine the industrial citizenship of mobile workers also prevent them from being effective free market agents: i.e., they can neither negotiate nor enforce individual contracts effectively in the face of systematic employer fraud and wage theft. The "Arendtian dilemma" of the "right to have rights" — a dilemma that derives from the claim that rights depend on the existence of a political community, which until now is the territorially exclusive nation-state, rather than universal personhood - emerges as industrial citizenship is internationalized. By disembeddeding workers from host-country industrial relations systems, EU regulation provides the social context in which workers' rights become alienable.
\end{abstract}

* University of Jyväskylä, Finland. Funded by ERC grant TWES \#263782. 


\section{INTRODUCTION}

The European Union (EU) is both a common market and a political entity with ambitions towards many nation-state prerogatives, including the establishment of an EU "citizenship," supplementary to the national citizenships of EU member states. Free movement plays a fundamental role in both the institutional construction and normative expectations of EU citizenship, ${ }^{1}$ but the current interpretation of free movement is more about market building than political or social citizenship. EU institutions promote mobility using a language of free market rights, with other aspects such as social and political citizenship dependent on economically motivated free movement. This basis is problematic because while market-economic rights are formulated on or transferred to the European scale, ${ }^{2}$ collective labor rights - i.e., industrial citizenship remain largely based in national systems, and for posted workers, inaccessible. While individual migrants are protected by equal treatment provisions when they move from one EU country to another, "posted workers," or workers sent by their employer to a foreign country, are quite explicitly not protected by equal treatment provisions, and have only limited rights to trade union representation.

This is a manifestation of the Arendtian dilemma of the "right to have rights." Arendt observed that human rights are effectively only realized through states and national communities. "The right to have rights" hinges on membership in a particular community, in practice meaning citizenship of a particular nation-state. ${ }^{3}$ Posted work delimits a labor market of workers who are partly "stateless" in an Arendtian sense: nominally entitled to a set of labor rights, but unable to claim these rights in practice because labor rights, like human rights generally, are exercised via national industrial relations systems, and posted workers are partially outside these systems. Subordination of worker rights does not occur directly, but rather via regulatory renegotiation of the

1 Chenchen Zhang, Territory, Rights and Mobility: Theorising the Citizenship/ Migration Nexus in the Context of Europeanisation (Apr. 16, 2014) (unpublished Ph.D. Dissertation, LUISS Guido Carli Univ. and Université libre de Bruxelles) (on file with author).

2 The market-economic rights referred to here are those designed to facilitate economically motivated free movement between EU member states (i.e., free movement of people, services, goods and capital). These rights are enshrined in the EU's founding Treaty of Rome, and their development has been the core theme of European Union jurisprudence. Treaty Establishing the European Economic Community, Mar. 25, 1957, 298 U.N.T.S. 3 [hereinafter The Treaty of Rome]. See in particular Articles 48 and 49.

3 Hannah Arendt, The Origins of Totalitarianism (1976). 
relationship between citizens and territories, contesting posted workers "right to have rights" rather than the rights themselves. This statelessness is in one sense accidental, resulting from the fact that posted workers exist between labor markets and regulatory systems, outside the jurisdiction of a particular national system. In another sense, however, it is deliberately constructed, as EU institutions legitimate exploitation of this situation as an expansion of "market freedoms," consistent with the EU's promotion of the mobile EU citizenship of market actors.

There are two aspects to the partial statelessness of posted workers. The first is that posted workers legally are only entitled to the same standards of employment as domestically recruited workers in a limited number of areas, which are exhaustively enumerated in the Posted Workers Directive. ${ }^{4}$ These limitations allow a cost advantage to posted workers over domestically recruited workers in some circumstances, even when the rules are followed judiciously. ${ }^{5}$ The second, and perhaps more important, aspect is that EU institutions have constructed a rule system that does not allow for effective enforcement of national labor regulations in all but a small minority of cases. ${ }^{6}$ This ensures that the rules are rarely followed judiciously; rather, the rules system is a cloak behind which employers can hide labor violations and only rarely be taken to task. Hanging over the enforcement issue is the hard fact that the imposition of any sort of labor standards on posted work impinges on the rights of employers to freely provide services in the EU. ${ }^{7}$

Posted workers, however, do not just have their rights stripped away via external compulsion, but rather via individual and possibly implicit negotiations with their employers. Because workers can theoretically choose whether to seek posted work or look for work in host countries themselves, accepting posted work involves an implicit bargain between the posting firm and the posted employee that host-country rights will not be evoked. Admittedly, it is a one-sided bargain — as David Ellerman would put it, a "Hobbesian bargain" 8

4 Directive 96/71/EC, of The European Parliament and of the Council of 16 December 1996 Concerning the Posting of Workers in the Framework of the Provision of Services, 1997 O.J. (L 018) 18/1.

5 Nathan Lillie, Subcontracting, Posted Migrants and Labour Market Segmentation in Finland, 50 Brit. J. Indus. Rel. 148 (2012).

6 Lisa Berntsen \& Nathan Lillie, Breaking the Law? Social Dumping in a PanEuropean Labour Market, in Market ExPansion And Social Dumping In Europe 43 (Magdalena Bernaciak ed., 2015).

7 See Case C-396/13, Sähköalojen ammattiliitto ry v. Elektrobudowa Spolka Akcjjna, 2014 EU:C:2014:2236 (opinion of A.G. Wahl).

8 David Ellerman, Translatio Versus Consessio: Retrieving the Debate About Contracts of Alienation with an Application to Today's Employment Contract, 
in which workers are "alienated" from their rights — but a bargain nonetheless. Workers can (and often do) move as individuals rather than as dependent employees. When they do, EU rules consider them as passing fully into the labor market and regulatory regime of the host country. Unlike posted workers, individual migrants are unambiguously formally entitled to the same labor rights as native workers, and are indeed protected by EU "equal treatment" standards. Contrarily, for posted workers, the EU protects instead the employer's right to seek a competitive advantage by exploiting wage differentials. Promoting "equal treatment" of posted workers potentially violates the free movement rights of employers, by making the employer less labor-cost competitive. ${ }^{9}$

Whether labor rights can and should be inalienable — i.e., whether they are the sort of rights which a person can voluntarily waive - is often contested by host-country actors such as unions, who try to apply host-country standards, at least those enumerated in the Posted Workers' Directive, ${ }^{10}$ to posted workers, with varying degrees of success. Because the employment conditions of posted workers often violate local law and practice, ${ }^{11}$ the bargain between worker and employer remains informal and implicit, and hence subject to arbitrary post facto redefinition by the employer. Free movement, as currently regulated through the intersection of EU and national rule systems, is about constraining the ability of unions and other regulatory actors from intervening in this understanding between posted workers and their employers. The EU imposes a market-citizenship logic, with the goal of protecting and encouraging workers' market autonomy. However, the ability of workers to exercise this autonomy is limited, because the dynamics which strip them of their rights

33 Pol. \& Soc'y 449 (2005).

9 Stein Evju, Revisiting the Posted Workers Directive: Conflict of Laws and Laws in Contrast, 12 Cambridge Y.B. Eur. Legal Stud. 151 (2009); Jan Erik Dølvik \& Jelle Visser, Free Movement, Equal Treatment and Workers'Rights: Can the European Union Solve Its Trilemma of Fundamental Principles?, 40 INDUS. REL. J. 491 (2010).

10 Directive 96/71/EC, supra note 4.

11 See, e.g., Bernsten \& Lillie, supra note 6; Jan Cremers, Free Provision of Services and Cross-Border Labour Recruitment, 34 PoL'y STUD. 201 (2013); Nathan Lillie \& Markku Sippola, National Unions and Transnational Workers: The Case of Olkiluoto 3, Finland, 25 Work, EmP. \& Soc'y 1 (2011); Guglielmo Meardi, Antonio Martin \& Mariona Lozano Reira, Constructing Uncertainty: Unions and Migrant Labour in Construction in Spain and the UK, 54 J. Indus. ReL. 5 (2012); Ines Wagner \& Nathan Lillie, European Integration and the Disembedding of Labour Markets: Transnational Labour Relations at the European Central Bank Construction Site, 52 J. Соммоn Мкт. Stud. 403 (2014). 
to act collectively also jeopardize their capacity to act as autonomous market actors.

This Article starts with Part I discussing the concept of industrial citizenship, which forms the basis for realization of labor rights. Next, it is shown how the concept of homo economicus undermines industrial citizenship by advancing the myth of the individual as an autonomous market actor. Post-national EU citizenship and the construction of mobility rules in the EU configure mobile workers as homo economicus, partially outside and unprotected by national institutions. Part II shows how firms exploit the gaps between national regulatory sovereignties, and the free movement protections they enjoy, by cheating their workers. Part III next discusses how workers largely acquiesce, refusing the overtures of unions and labor inspectorates of host countries to pursue action against their employers because they are aware that these organizations cannot protect their interests. The Conclusion argues that the EU provides the regulatory context in which workers may waive their "right to have rights."

This Article is based on over two hundred interviews conducted during 2011-2015 in the framework of the project Transnational Work and the Evolution of Sovereignty (TWES). A team of researchers interviewed posted workers, unionists, managers, and labor inspectors in Germany, Finland, the Netherlands and the United Kingdom. Most of the workers interviewed were from Eastern European countries, and a minority from southern Europe (typically Portugal or Spain) or elsewhere. All interviewees are anonymous, following the project's human subjects' ethical policy.

\section{Citizenship and Transnationality in the EU}

\section{A. Industrial Citizenship}

The right to have rights invokes notions of citizenship, which is both an analytical and normative concept tying individuals to society. "Industrial citizenship," a term originally coined by T.H. Marshall, is generally interpreted to mean the exercise of voice in the workplace, and respect for labor rights. It is closely tied to union representation. ${ }^{12}$ In Marshall's classic analysis, the realization of industrial citizenship incorporates the working class into the polity, helping to resolve the problem of exclusion due to poverty. Social and industrial citizenship are close conceptual cousins, as Marshall's argumentation

12 T.H. Marshall, Citizenship and Social Class (1992); see also Walther MuellerJentsch, Productive Forces and Industrial Citizenship: An Evolutionary Perspective on Labour Relations, 12 Indus. \& ECON. DEMOCRACy 439 (1991). 
makes clear. ${ }^{13}$ The industrial relations discipline has a highly developed notion of industrial citizenship in practice, i.e., expressing voice in firms, protecting rights, and defending interests, ${ }^{14}$ although the term "citizenship" is rarely used. Industrial citizenship, despite the long history of the term, remains underdeveloped within citizenship studies. Herein it is defined in Arendtian terms. If "citizenship is the right to have rights" 15 then industrial citizenship is the right to have labor rights.

Modern citizenship, industrial or otherwise, is embedded in capitalism and the territorial state system. ${ }^{16}$ Since rights are realized through territorial entities, access to rights depends on where physically an individual is situated, and what his or her citizenship status is in relation to that territory. ${ }^{17}$ Because territorial states govern dynamic economies with changing governance, citizenship is not a static object but rather an ongoing relational process, defining roles, hierarchies and relationships in society, changing with evolving notions of territoriality and shifting productive structures. Furthermore, people move, as do state boundaries, opening the possibility for noncitizens within states, creating tensions about who has access to what rights. ${ }^{18}$ The right to have labor rights must be problematized not only in terms of states and territoriality, but also in terms of organizational membership. Unions (and sometimes works councils) are the primary vehicles for industrial citizenship, and access to these is variable across countries and workplaces. Industrial citizenship is in a macro-sense realized through nation-states, and bounded by their territories; ${ }^{19}$ in a more immediate sense it is embedded in the (power) relationship of workers and employers, relying on structural power derived through class-based collectivism. ${ }^{20}$ This means that industrial citizenship is

13 MARShALL, supra note 12.

14 Richard Freeman \& James Medoff, What Do Unions Do? (1984).

15 ARENDT, supra note 3, at 31.

16 Margaret Somers shows how notions of citizenship in early modern England grew out of intertwined processes of economic development and national territorial consolidation. Modern citizenship met the requirements of complex economies and larger scales of social organization better than the feudal ties and hierarchies it replaced. Margaret Somers, Citizenship and the Place of the Public Sphere: Law, Community, and Political Culture in the Transition to Democracy, 58 Ам. Soc. Rev. 587 (1993).

17 ARENDT, supra note 3.

18 Rainer Bauböck, Towards a Political Theory of Migrant Transnationalism, 37 InT'L Migration Rev. 700 (2003).

19 Charles Tilly, Globalisation Threatens Labor's Rights, 47 InT'L LAB. \& WorkINGClass Hist. 1 (1995).

20 Chenchen Zhang \& Nathan Lillie, Industrial Citizenship, Cosmopolitanism and 
not just the right to have rights within the state system, but also a process and relationship between worker(s) and employers - i.e., the right to have labor rights within a particular employment context, which also has contested boundaries. Inevitably, industrial citizenship rights are variegated depending on bargaining units and collective agreement coverage; employers also strategize around those cleavages to create groups of workers with less access to rights. For example, by outsourcing, employers can undermine access to union or works council representation. ${ }^{21}$

Mechanisms of industrial citizenship placed class-based political formations at the center of national politics in Western Europe since the end of the Second World War, and permitted the partial decommodification of labor through welfare states. ${ }^{22}$ The logic of national citizenship concealed class-based differences by submerging working-class identities into national ones, but at the same time absorbing working-class demands into national economic management. ${ }^{23}$ With the decline of these principles, the emergence of marketbased notions of citizenship is unsurprising.

\section{B. Market Citizenship}

Market citizenship seeks to enable people as market actors, assuming they will and must realize themselves via autonomous and individual market behavior. The homo economicus archetype is a market citizen, who embodies the core assumptions of mainstream economics about human behavior. Many have noted that these assumptions do not actually hold. However, this misses the point, as economists are as aware as anyone that economical rationality does not determine, or even much influence, economic behavior. Rather, "economic man" is an analytical construct, and "useful as a guinea pig for what could be accomplished." 24 Homo economicus is an ideal which can be achieved through appropriately designed policies, by rewarding desired behavior through market

European Integration, 18 Eur. J. Soc. THEORY 93 (2015).

21 Virginia Doellgast \& Ian Greer, Vertical Disintegration and the Disorganization of German Industrial Relations, 45 BRIT. J. INDUS. REL. 55 (2007).

22 Gøsta Esping-Anderson, Three Worlds of Welfare Capitalism (1990).

23 This is what Gramsci means with the notion of hegemony. See AnTONIO GramsCI, The Modern Prince, in Selections from the Prison Notebooks 313 (Quitin Hoare $\&$ Geoffrey Smith eds., 1971). Similar notions are also found in sociological accounts of citizenship and capitalism. See Bryan Turner, Citizenship and Capitalism: Debates over Reformism (2014).

24 Joseph Persky, The Ethology of Homo Economicus, 9 J. Econ. PersP. 221 (1995). 
incentives and punishing undesired behavior. ${ }^{25}$ This is normative; although people do not behave like homo economicus, economists believe they should.

Critical discussion often makes homo economicus out as a powerful, autonomous market actor, with undesirable effects of his behavior stemming from the undermining of the bonds that hold society together. ${ }^{26}$ Ironically, homo economicus might not be found so much in the realm of societies' powerful autonomous actors, such as corporate board members or policymakers, but rather in the realm of those who are subject to their decisions. Powerful individuals do as they wish regardless of economic rationality, but those who live on the margins might not enjoy this luxury. Aihwa Ong points out that the increasing emphasis on "market norms of citizenship" and governance ensures that the security, wellbeing and quality of life of citizens are increasingly dependent on their capacities as free individuals to confront globalized insecurities by making calculations and investments in their lives. ${ }^{27}$ In other words, full participants in the new society must use market power for their own ends, rather than be used by the market powers of others. As Margaret Somers writes, "market incentives" are often used to compel "utility maximizing behavior," particularly focusing on legitimating the reduction of social benefits for the poor. ${ }^{28}$ For example, Ian Greer and Virginia Doellgast point out that unemployed people are often subject to "activation policies" which "seek to affect transactions on the labor market by increasing the number of job seekers in low-wage occupations and reducing the reservation wage." 29 This marketizes labor by turning many diverse forms of labor into a cheap, standardized commodity. ${ }^{30}$ Homo economicus is constructed out of reluctant subjects, who are made vulnerable to this imposition by unfortunate circumstances.

Globalization goes hand in hand with the increasing importance of market citizenship, as it provides contexts for sidelining national citizenship, contesting established rights by going around them. This is enabled by the fact that although citizens of different countries may be entitled to equality within

25 Margaret Somers, Genealogies of Citizenship: Markets, Statelessness, and the Right to Have Rights 19, 30 (2008).

26 See Elizabeth Anderson, Beyond Homo Economicus: New Development in Theories of Social Norms, 29 Phil. \& PuB. AfF. 170 (2000).

27 Ainwa Ong, Neoliberalism as Exception: Mutations in Citizenship and Sovereignty 551 (2006).

28 Margaret Somers, Genealogies of Citizenship: Markets, Statelessness, and the Right to Have Rights, 22 Trajectories 30 (2011).

29 Ian Greer \& Virginia Doellgast, Marketization, Inequality, and Institutional Change 9 (Univ. Greenwich Bus. Sch., Working Paper No. 5, 2013), http://gala. gre.ac.uk/10294/1/WERU5_Greer_Doellgast_working_paper.PDF.

30 Id. 
their own country, their countries are not equal. The details are different in different contexts, but for posted workers, market forces are introduced through the transnationalization of the labor market regulation and the alienability of labor rights this implies. As Ong puts it, "the infiltration of market logic into politics conceptually unsettles the notion of citizenship as a legal status rooted in a nation-state, and in stark opposition to a condition of statelessness." ${ }^{\prime 31}$

In the posted worker, the EU constructs its version of homo economicus for political purposes, by creating a hegemonic discourse legitimating coercive interventions which undermine worker power, in politics and in markets. It does so in ways that deliberately construct borders as permeable and flexible for capital, but constraining for national regulators and trade unions. ${ }^{32}$

\section{EU Citizenship}

European integration is ideologically based on market ideas,${ }^{33}$ so it is unsurprising that the implementation of EU citizenship is primarily about building markets and enabling individuals as autonomous market actors. In EU political forums, there has been little space for class-based politics or recognition of the centrality of class-based politics in organizing national political systems. ${ }^{34}$ Mobility and economic autonomy are foundational ideas in constructing a market-based post-national EU citizenship. A floating workforce, able to redeploy quickly to areas where labor is scarce and away from areas where it is in oversupply, is an economist's ideal: freed from institutional constraints and sociocultural barriers, labor can go where it can be efficiently used, and leave again when the job is finished. This notion of a fluid pan-European labor market is at odds with the traditional narrative of migrants as provisional citizens, who come in search of a better life in the host country, eventually to assimilate and

31 ONG, supra note 27, at 16.

32 Ines Wagner, Posted Work and Deterritorialization in the European Union (Mar. 28, 2015) (unpublished Ph.D. Dissertation, Univ. of Jyväskylä) (on file with author).

33 Nicolas Jabko, Playing the Market: A Political Strategy for Uniting Europe, 1985-2005 (2006).

34 While the political systems of Western European countries were essentially built around resolving class conflict, see, e.g., Colin Crouch, Industrial Relations AND EuROPEAn State Traditions (1993), the EU has its origins in an international treaty, and its design still for the most part reflects the need to resolve conflicting state interests, with class interests only weakly developed, see, e.g., Phillippe Schmitter, How to Democratize the European Union ... and Why Bother? (2000). 
become full citizens and participants in society. ${ }^{35}$ Of course, the reality of EU citizenship is more complex; various contradictory ideas exist, although the starting point has always been justifying mobility through opening of markets.

The mobility of workers as individuals instead of posted workers presents a very different dynamic, at least in terms of de jure rights. The issue of employment and social rights for individually mobile EU citizens emerged in the early days of the EU, based on the Treaty of Rome. ${ }^{36}$ Labor mobility did not remain isolated from other policy areas: questions of rights to social security, mobility of family members and the like required answers, so that over time there was a shift towards a social rights approach. Regular migrants who move as individuals pass fully into the labor markets and social security systems of host countries, and are entitled to equal treatment provisions with native workers, meaning the full array of national labor and social rights. ${ }^{37}$ These include the rights to work, draw social benefits, send their children to school, etc. Although beginning as extensions of the right to free mobility of labor, they have decommodifying implications. ${ }^{38}$

Whether based on individual or dependent worker mobility, EU mobility regulation is designed around a set of stylized "facts" about people and societies which reflect neither the people nor the societies, but which fit very well with the notion of homo economicus as a powerful, individualistic, and independent agent. Accordingly, the logic unfolding from EU regulatory frameworks seeks to enable mobile workers as individual market actors, who are presumed to be powerful, individualistic and independent, but constrains and represses them as collective ones, because of the presumed negative effects their collectivism would have on labor-market functioning and free movement. ${ }^{39}$ The difference is not so much in how the EU approaches mobility, but in how European regulations articulate with national systems; although individual migrant rights are based on the assumption that they are units of labor rather than people, they are nonetheless embedded in national systems, which do not treat them only as factors of production. Individual migrants have a right to have rights, and their labor rights are therefore not alienable.

35 Erka Caro, Lisa Berntsen, Nathan Lillie \& Ines Wagner, Posted Migration and Segregation in the European Construction Sector, 41 J. Ethnic \& Migration STUD. 1600 (2015).

36 The Treaty of Rome, supra note 2, arts. 48, 49.

37 Dølvik \& Visser, supra note 9.

38 Claire Marzo, A Dual European Social Citizenship?, in Before and After the Economic Crisis: What Are the Implications for the European Social Model 170 (Marie-Ange Moreau ed., 2011).

39 Sippola Markku, The Awkward Choices Facing the Baltic Worker: Exit or Loyalty, 44 J. BALtic STUd. 451 (2013); Somers, supra note 28. 
Much labor mobility in Europe occurs as posting. ${ }^{40}$ When an employer sends an employee abroad to perform a job, the regulatory framework falls under the free movement of services rather than the free movement of workers, activating a different set of worker rights. ${ }^{41}$ Certain aspects of host-country social security systems and labor rules do not apply to posted workers, as they do to migrants who move on the basis of the free movement of workers. Posted workers exist in a regulatory sense between two or more nation-states, and have their rights guaranteed by both countries and neither. Posted workers operate between countries as autonomous market actors, who may therefore waive their labor rights. ${ }^{42}$ Because there are multiple sets of rights which could apply to a given mobile worker's situation, the actual outcome is indeterminate and depends on negotiation with their employer. In a theoretical sense, there are many possible outcomes; in a practical sense, it usually comes down to the power relationship. "Rights" become a reflection of labor market knowledge, power and negotiating acumen.

40 It is difficult to assess the scale of the labor market impact of individual versus dependent mobility, because in practice posted work is used mostly as one form of regulatory avoidance among many, and employers readily shift to other forms - for example, illegality, domestically arranged temporary work, or bogus self-employment - depending on the regulatory framework of the host country. Thus, the organizational forms of posted work and their legal use do not always match up, and employers seeking to avoid enforcement will often put their workers under posting contract ex post facto. Furthermore, the numbers that are available are unsuitable for EU-level analysis because of highly variable national data collection, and measure only flows, which makes it conceptually problematic to compare them with figures of immigrant stocks. Nonetheless, there are probably several million immigrants from Eastern Europe residing in Western Europe, while formally registered posted workers are counted in one Commission report to number 1,510,000 in 2011. See Béla Galgoóczi, Janine Leschke \& Andrew Watt, Intra-EU Labour Migration: Flows, Effects, and Policy Responses (Eur. Trade Union Inst., Working Paper 2009.3, 2011), for a discussion of migration stocks. See Eur. Comm'n, Employment, Social Affairs and Inclusion, Dg Posting of workers in the European Union and EFTA countries: Report on A1 Portable Documents issued in 2010 And 2011, at 3 (2013), for estimations of posted worker numbers.

41 Evju, supra note 9.

42 Lisa Berntsen, Agency of Labour in a Flexible Pan-European Labour Market: A Qualitative Study of Migrant Practices and Trade Union Strategies in the Netherlands 526 (June 13, 2015) (unpublished Ph.D. Dissertation, Univ. of Jyväskylä) (on file with author). 
Regulatory possibilities are in part defined by the European framework. The Posted Workers Directive (PWD), passed in $1996,{ }^{43}$ establishes that posted construction workers are entitled to the statutory minimum conditions of either their host state or sending state, whichever is better from the worker's perspective, thus allowing national regulation of employment at transnational subcontractors. The PWD, however, protects only a "hard core" of posted worker rights, ${ }^{44}$ and these only theoretically, leaving windows of opportunity for labor-cost competition. ${ }^{45}$ This seeming subversion of the purpose of the Posted Workers Directive occurs because there is space for labor-cost savings in many contexts while complying with the directive. ${ }^{46}$ Furthermore, enforcement is very difficult, so noncompliance with labor regulation is more the rule than the exception. ${ }^{47}$

\section{Firms' Practices and Union Organizing}

Markets are often described as voluntary transactions between free and autonomous individuals. Implicit in this is the assumption that states have coercive ability but other actors do not. The policy basis for promoting free markets is that humans are rational economic actors who will be utterly ruthless in pursuit of their economic goals, but only within the rules of economic exchange: i.e., they will not lie, cheat nor use violence. ${ }^{48}$ As Samuel Bowles and Herbert Gintis put it, homo economicus lives in a "charmingly Victorian but utopian world in which conflicts abound, but a handshake is nonetheless

43 Directive 96/71/EC, supra note 4.

44 The Directive specifies which categories of employment conditions it regulates; these are: (1) maximum work periods and minimum rest periods; (2) minimum paid annual holidays; (3) the minimum rates of pay, including overtime rates (this point does not apply to supplementary occupational retirement pension schemes); (4) the conditions of hiring-out of workers, in particular the supply of workers by temporary employment undertakings; (5) health, safety and hygiene at work; (6) protective measures with regard to the terms and conditions of employment of pregnant women or women who have recently given birth, of children and of young people; and (7) equality of treatment between men and women and other provisions on nondiscrimination. See id.

45 Wagner \& Lillie, supra note 11.

46 Lillie, supra note 5.

47 Cremers, supra note 11.

48 Stergios Skaperdas, Restraining the Genuine Homo Economicus: Why the Economy Cannot Be Divorced from Its Governance, 15 Econ. \& Pol. 135 (2003). 
a handshake." ${ }^{49}$ Under such conditions, if states and trade unions lose their powers to enforce labor contracts, firms will still agree contracts with workers. However, they will do so at free market rates, which may be lower or higher than before, but probably lower because of the loss of the monopoly power of unions. In the real world, in the absence of regulation, workers have trouble concluding enforceable contracts, firms do not regard themselves as having contractual obligations to their workers, and workers face a real risk that they will not always be paid what they are owed, or perhaps will not even be paid at all. Workers cannot behave as labor market actors in the real sense, but only as supplicants to employers. Power and control of information become as important as supply and demand in the operations of the labor market, with employers using a variety of strategies to deceive and intimidate their workers.

Firms' power, however, is fragile, because it depends on the workers continuing to waive rights. To sustain this, firms must prevent unions and labor inspectors from tempting their workers with the promise of much better pay, often enforceable post hoc, if they cooperate in pursuing industrial or legal action. Posted workers by and large come from host countries where wage levels are lower, worker representation weaker, and relationships to management more hierarchical. Furthermore, informal work relations are more common, and labor rights violations more frequent. ${ }^{50}$ In this respect, posting firms merely keep intact the employment relations of the sending country. Formal legal structures are only part of the biopolitical technology of posting: in order for regulatory sovereignty to be held at bay, posted workers must continue to regard their employment and social world as extraterritorial, and to tolerate the segregation which cuts them off from host-country society. One aspect of manufacturing extraterritoriality is continuing the legal distinctiveness, but it is also about maintaining ethnic hierarchies, market norms and a degree of acceptance of these things by all the actors involved.

Workers are typically recruited in their home country by a contractor or work agency. This firm presents the posted worker with a contract governed by the laws of the country where that firm is incorporated, which is normally the country where the worker is from. Alternatively, it may be a country chosen by the employer, where the firm has a letterbox subsidiary. Sometimes workers are allowed to read their work contracts, sometimes not. Sometimes there are two contracts with different conditions, to be presented to different

49 Samuel Bowles \& Herbert Gintis, The Revenge of Homo Economicus: Contested Exchange and the Revival of Political Economy, 7 J. Econ. Persp. 83 (1993).

50 Charles Woolfson, Pushing the Envelope: The 'Informalisation' of Labour in Post-Communist New EU Member States, 21 Work, EMP. \& Soc'y 551 (2007). 
authorities. The CJEU Advocate General ${ }^{51}$ portrays this process of selecting a jurisdiction for governing the contract law as one of mutual agreement. $\mathrm{He}$ describes the decision process in the case of some Polish electricians sent to Finland as such: "the parties that have concluded the employment contracts have expressly chosen Polish law as the law that ought to govern the terms of employment of the workers concerned." ${ }^{2}$ This follows the market view of individual workers as autonomous market actors.

Of course, what really happens is the employer decides - sometimes even changing the governing law of the contract without telling the worker. This decision of country in which to base the work contract has implications for the labor standards and social security which apply. It is absurd to believe that individual workers are navigating the intricacies of international labor law themselves, or that there is some kind of negotiation or agreement occurring around it. At best, they are given a deal and they can take it or leave it; at worst, they do not have a deal with clear terms, or the deal they are given is deceptive. In the existing situation in which workers are unable to enforce contracts by themselves, but in which labor inspectors and especially trade unions often stand ready to help workers who feel aggrieved, maintaining the system requires intimidation.

For example, the findings from our investigation of the construction of the European Central Bank (ECB) towers in Frankfurt shed light on how exceptional spaces are created. As Wagner and I found, it was not just one factor, but a combination of legal barriers, works councilor disinterest, organizational boundaries between firms, lack of union capacity and familiarity with subcontracting firms, and weak wage agreements that maintained the exceptional space at the ECB site. Unionists found it difficult to access the site, as the management claimed "extraterritoriality," based on the fact that the ECB is an international institution. Almost all the workers on the site were foreigners, working for foreign-based subcontractors. These firms had no contact with trade unions, and no works councils of their own. Works councilors from the (German) main contractor had no legal right to represent the workers of the subcontractors. Foreign workers expressed in interviews that they had few options to express workplace concerns, and nowhere to go if they felt mistreated..$^{53}$ One German trade association representative noted:

The ECB is a very ominous site. It is something that our members and we are not happy with. ... It is extraterritorial territory and the

51 Case C-396/13, Sähköalojen ammattiliitto ry v. Elektrobudowa Spolka Akcjjna, 2014 EU:C:2014:2236 (opinion of A.G. Wahl).

52 Id. at 11.

53 Wagner \& Lillie, supra note 11. 
German rules and law does not apply there. They have barbed wire around the whole site which is already an indication that they want to shut themselves off. ${ }^{54}$

Employers often point to such bad behavior as something they themselves (or in the above interviewees' case, presumably the association members) would not do, but at other sites around Europe unions and labor inspectors relate similar experiences, with management restricting site access by various means. ${ }^{55}$

Finally, since workers themselves might also of their own initiative seek to contact unions or labor inspectors, the consequences of doing so need to be evident. The firm Atlanco Rimec is a leader in innovative labor intimidation strategies, which due to its size and profile has been discussed extensively within the labor movement, and in news exposés. It provides a good example of how these techniques are used. The first layer of defense in Atlanco Rimec's case is to try to prevent the implication that there is a relationship between the firm and worker which might imply obligations on the part of the firm.

When workers are dissatisfied and make demands, Atlanco Rimec uses its presence in multiple countries to shift the responsibility around and ensure that Altanco Rimec is not obligated to pay anything. ${ }^{56}$ Atlanco Rimec is actually a network of companies, which appear in many cases to be shell firms created with the goal of avoiding legal responsibility. Workers' employment can be moved from one company to another, as is illustrated by an excerpt from an Atlanco Switzerland employment contract of 2012: “The company reserves the right to transfer the employee at any time to other companies of the group of which the company is a member on similar terms within the period of the agreement. ${ }^{" 57}$ Since the first step in any process of complaint is normally for the employee to petition the employer, the firm makes itself difficult to contact. One former employee relates:

When the first pay slips arrived, it did not provide us with any information, except for my last name, the company name, and a mysterious logo.

54 Interview with anonymous attorney, Verband Baugeswerblicher Unternehmen Hessen, in Frankfurt, Ger. (Apr. 25, 2011).

55 See Nathan Lillie, Markku Sippola \& Lisa Berntsen, A Tale of Two Power Plants: Labour Mobility and the Deregulation of Industrial Relations at the Olkiluoto 3, Finland, and Eemshaven, Netherlands, Construction Sites, CLR News: Climate Change \& Construction Lab., Dec. 2011, at 23.

56 The Treatment of Foreign Workers by Irish Firms (RTE news television broadcast Nov. 6, 2014), http://www.rte.ie/news/player/2014/1106/20677365-the-treatmentof-foreign-workers-by-irish-firms/.

57 Anna-Lena Norberg, Atlanco Rimec, Speech at EFBWW Conference on European Federation of Building and Woodworkers, Brussels, Belg. (Jan. 23, 2013). 
The agency's address is not on there, nor my personal identification number. There are no separate entries for pension or social security or tax payments. There is only a general sum. This is very secretive..$^{58}$

In the course of the TWES project research, we had occasion to speak with a number of workers who were working or had once worked for Atlanco Rimec. We did not find any that seemed happy with their jobs, and many had very harsh words indeed for the company. For example, the abovementioned Atlanco Rimec worker whom we interviewed explained:

Atlanco Rimec is a dangerous firm because it abuses people . . . . It abuses the law ... by stretching it to find ways to circumvent it, only to rob us. It is a criminal agency. This is the first and last time that I work with them. ${ }^{59}$

While many Atlanco Rimec workers refused to be interviewed - and it is always possible they refused because they were so happy - the circumstances and demeanor of their refusals suggested fear rather than satisfaction. It is informative to look at remarks made about worker performance in Atlanco Rimec's internal database, in which management keeps detailed information about all workers who have worked for them, including reasons for dismissal, and whether they are recommended for reemployment. From these entries, it is clear that Atlanco Rimec systematically dismisses workers who are perceived as pro-union, or who complain about pay and conditions. Some of the entries explicitly mention union sympathies or union activities, e.g., "talks to unions and tries to find problems unnecessarily," while others more vaguely mention "troublemaking" or "turning the other workers against the company." 60

Despite evidence of dissatisfaction and occasional flare-ups of industrial action, workers generally accepted this treatment as their due. In the TWES project, we observed Atlanco Rimec intimidating some of their workers back to work, when some Polish workers working at the Eemshaven construction site in the Northern Netherlands complained to the union about mysterious paycheck deductions. Some of them were fired right away for talking to the union, which scared the rest, as the union said it could not help them unless they would show their pay slips. Instead they went to the client firm, Fabricom, a contractor on the site. Fabricom told them that if it acted, it would be by firing Rimec as a labor agency, which would mean they would lose their jobs anyway. Although the workers were angry, in the end they went back to

58 Interview with anonymous agency construction worker, Atlanco Rimec, in Wagenborgen, Neth. (Nov. 26, 2011).

59 Id.

60 These are reasons cited in Atlanco Rimec's internal database. 
Rimec, which moved them to a different site. Atlanco Rimec's own records and incident descriptions from other cases suggest that this is a common pattern, rather than an isolated case. ${ }^{61}$

Furthermore, it is hardly the only firm which does this, though it is the perhaps the largest and most professionalized; most firms are smaller, less professional, operations. ${ }^{62}$ These firms are an established part of the labor market in construction and sometimes in other industries. While not all firms are as systematic, Atlanco Rimec and firms like it set the tone and competitive dynamic by normalizing conduct which some would find morally dubious. ${ }^{63}$ Atlanco Rimec's strategy, and the fact that it is supported and encouraged by EU regulation, raises a question mark not only over the rights of workers to collective representation, but even their rights as autonomous market actors to individual contracts, and to effective access to the social benefits they pay for out of paycheck deductions.

If there were a functional labor rights framework to which the posted workers could turn, i.e., if posted workers had the "right to have rights," firms like Atlanco Rimec would only operate, if at all, on the margins of the temporary work industry, but not work openly for large, respectable client firms. On occasion Atlanco Rimec is fined or "fired" as a labor provider, although these actions have not always worked out well for the workers in question. These firings might have more to do with clients setting examples to intimidate workers at other firms on-site. Nonetheless, although Atlanco Rimec's strategy accrues penalties and loses clients, these losses are almost certainly minor compared to the profits gained from large-scale wage theft and avoidance of social fees (the financial position of the company is secret because it is incorporated offshore).$^{64}$ One can surmise that Atlanco Rimec regards these costs as the price of doing business, ultimately less costly than keeping its end of what workers would normally regard as employer obligations. This is to say, the self-positioning of Atlanco Rimec as outside any legal system and social norms is not uncontested nor costless, but ultimately sustainable given the EU regulatory framework, the difficultly of enforcement, and the constraints put upon union activity.

61 Berntsen \& Lillie, supra note 6; Lillie \& Sippola, supra note 11; Anna-Lena Norberg, NCC, Atlanco and the Lies, StopPAFuSKet (July 2, 2012), http://www. stoppafusket.se/2012/07/02/ncc-atlanco-and-the-lies/; The Treatment of Foreign Workers by Irish Firms, supra note 56.

62 Berntsen \& Lillie, supra note 6.

63 Id.

$64 I d$. 


\section{Exit, Voice and Mobility in a Pan-EU Job Market}

Posted workers confront an incentive structure which enforces market rationality by design, but they confront it without the power to ensure that their employers respect the rules as well. They cope with the spotty and highly contingent regulation, low and variable wages, short-term contracts and little job security, and no effective options for workplace voice, through mobility. ${ }^{65}$ This mobility helps to reinforce employers' strategies of isolating the workers from hostcountry standards. ${ }^{66}$ They normally turn to collective action or enforcement authorities when their conditions are truly unacceptable, their employers have abandoned them and all other recourse has failed. Enforcement normally occurs either through an external agency, such as state labor inspectors, or more usually, through the assistance of trade unions and associated migrant rights groups. Thus, the weakness of collective organization and the enforcement difficulties experienced by state labor inspection have resulted in an epidemic of wage theft, as employers ruthlessly exploit opportunities to control their workforce and minimize their wage bills. ${ }^{67}$

Because no worker will work for an employer which he or she knows will not pay at least the reservation wage, employers use sleight of hand, preying on hopes and good faith. Once the posted worker is engaged and working, the reservation wage is lower, because the sunken costs of accepting the posting have already been paid. There is therefore the potential for systematic dishonesty to be a viable strategy for firms. The efficient functioning of labor markets is limited by the inherently limited capacity of workers to assess, negotiate and enforce their work contracts. The rationale behind the EU regulatory framework and legal reasoning expects and demands that each and every migrant bricklayer, meat cutter or pipefitter be an expert in EU and national employment law to be able to conclude appropriate contracts. This is not in any way to cast aspersions on the capacities of posted workers, who may be skilled professionals in their own areas, but if they were as skilled at international labor law as international labor lawyers, they would probably be international labor lawyers, and if they had the resources to engage international labor lawyers to check their work contracts, they would probably not work on construction sites for eight euro per hour.

Of the posted workers interviewed in the TWES project, the majority would fit the definition of what the migration literature calls "target earners," or workers who work abroad to achieve a certain monetary "target," and once

\footnotetext{
65 Berntsen, supra note 42.

66 Caro, Berntsen, Lillie \& Wagner, supra note 35.

67 Cremers, supra note 11.
} 
this is earned, return home ${ }^{68}$ Posted workers' strategies are defined more by the pan-EU labor market of their industry and craft, and less by geography - that is to say they follow particular job opportunities wherever these may be. Posted workers are pushed away from home due to low wages and few opportunities and pulled abroad by higher wage levels and arranged and covered expenditures for travel and housing. In this sense, there can be said to be a pan-EU labor market, with price signals sending workers across a variegated landscape of industrial relations systems and social regimes to take up jobs wherever they are needed, and quickly moving on when they are not.

Some workers emphasize the market power that the ability to "exit" a given situation gives them. As Berntsen shows, posted migrants use mobility between worksites as an alternative to voice mechanisms, which for them are usually blocked. Through mobility and small acts of resistance they improve their bargaining leverage within the market system, but rarely challenge it outright, ${ }^{69}$ because resistance comes at a high personal cost. In the TWES project, we only noticed outright resistance in cases where living or working conditions became intolerable, when workers were paid much less than promised (or began to suspect they would never be paid at all), or when there was a serious job site accident. This is to say, the posted workers realized and accepted the "deal" they have made: they accepted their labor rights as "alienable," i.e., that as a condition of employment, they would not be entitled to the same labor rights as the citizens of host-country states.

Hypermobile workers can usually expect a wage premium relative to what they would receive at home, and this is a common motivation for moving. This was not always the case, however; they sometimes were paid similar or lower wages than at home, but accepted the position to avoid unemployment. The hypermobile lifestyle involves a high degree of uncertainty; workers expect that they can be dismissed at any time, and realize they may have to move to another job, perhaps in another country:

Interviewer: Do you always know how long you will stay?

Interviewee: It is a lottery ... . I can get [notification] Friday afternoon ... that I have to pack my stuff, and that I don't need to come back Monday. That is how the firms work, in this way. There is contractor, a subcontractor, he gives a contract, and then at that moment there is work. ${ }^{70}$

68 Michael J. Piore, Birds of Passage: Migrant Labor and Industrial Societies (1979).

69 Berntsen, supra note 42, at 91-106

70 Interview with anonymous Polish pipefitter, in Eemshaven, Neth. (Nov. 26, 2011). 
Although, or perhaps because, the level of uncertainty is high, workers are sensitized to differences between countries, and network amongst each other in order to find out about and decide between opportunities in different countries. They perceive the pan-European space as a single labor market, with different wage levels and conditions in different locations:

A total of three times I had adventures with this company. Once in Germany, but before that I worked in Poland. The earnings there were very bad. Until I decided I couldn't do it [in Germany] anymore ... . I let myself be seduced into working in Germany because there was no work in Sweden, and I was only interested in working abroad. I worked three months in Germany but left because it was so bad. ${ }^{11}$

Some mobile workers have stable positions with good companies, with mobility occurring within their firms. These are in a different and better situation than those working for agencies or small gray-market subcontractors, and are often better paid and more reliable jobs. Others seemed to have internalized market norms and regard themselves as market players in their own right:

I am a mercenary. Today I am working for Infogesta tomorrow I am working for ... more money. ${ }^{72}$

A striking aspect of the interviewing process of posted workers is that, although they are doing legitimate work for ostensibly legitimate employers and have an uncontested legal status to be living and working in EU countries, they nonetheless behave as if they were illegal migrants whose employers could turn them in to the authorities to be deported at any moment. Often, workers we approached to interview would simply say that everything is fine at work (although this was not always the question asked), and those who talked would tell of less outgoing colleagues who they claimed were afraid to talk. ${ }^{73}$ Many interviewees involved in enforcement told of informal deals between managers and posted workers, in which the posted workers would claim to be paid more than the evidence suggested was possible. One Finnish labor inspector relates:

We went to the work site ... and there were some Estonian workers, that were posted workers, and we asked ... what their salary was. Their foreman, who spoke Finnish, said that every one of them got

71 Interview with anonymous Polish scaffolder, in Eemshaven, Neth. (Jan. 21, 2012).

72 Interview with anonymous Portuguese mechanic, in Eemshaven, Neth. (June 23, 2012).

73 Berntsen, supra note 42; Wagner, supra note 32. 
ten euros per hour. After that we checked the contract between the client company and the employer, which was an Estonian company ... and it said that some of the workers were being billed at ten euros per hour and some seven euros. So basically, what the contractor was billing the client for the workers was less than what the workers said they were being paid. When workers and employers do that kind of cash in hand deal, and say that the working conditions are other than what they are, then we are in practice pretty toothless, that is we don't really have any tools to do anything, if the people concerned are of the opinion that everything is ok. ${ }^{74}$

This experience is common and typical to labor inspectors and union officials in other western European countries in sectors where posted work is common. ${ }^{75}$ The mentality behind accepting this sort of employer behavior is that of the short-term migrant, who cannot afford to invest too much effort and risk into improving conditions in any particular location, because soon they will be moving on. As one Rumanian carpenter working in Finland told us:

You have to understand something: people come here, they leave their families at home and they come here to earn some money. They are not that interested to be part of the trade union . . . maybe for those who are living here these things have priority . . . . But, for many of them, they come here just to earn some money, to go home to their families, to do what is good for them . . . maybe that's why they think that being part of the trade union counts so little. ${ }^{76}$

This worker expresses what many interviewees felt. It is a typical pattern for short-term migrants, and has also been found by, for example, Thörnqvist and Bernhardsson in a recent study on Polish posted workers in Sweden, who note that their interviewees connect their acceptance of unfair treatment with the goal of achieving a "life project" back home. ${ }^{77}$ The motivation to resist is weak, but the potential personal cost of being seen as a troublemaker quite high, as one Polish electrical worker working in Germany explained:

74 Interview with anonymous labor inspector, Finnish Work Protection Agency, in Helsinki, Fin. (Sept. 1, 2006).

75 See Berntsen, supra note 42; Wagner, supra note 32.

76 Interview with anonymous agency carpenter, Finnish work agency, in Turku, Fin. (Aug. 11, 2011).

77 Christer Thörnqvist \& Sebastian Bernhardsson, Their Own Stories - How Polish Construction Workers Posted to Sweden Experience Their Job Situation, or Resistance Versus Life Projects, 21 TRANSFER 23 (2014). 
Why would a trade union help me? What would I get from that? Even if the union helped me, I wouldn't be able to stay here, because no one would hire me. ${ }^{78}$

We spoke with many trade unionists during the TWES project, and found that posted work is a widely recognized problem, particularly among construction unions, because of problems with poor treatment and underpayment, and the displacement of union members by posted workers. Much resourcefulness and creativity has gone into finding ways to represent posted workers, with only limited and short-lived success. Among other things, the problem is that posted workers are so mobile. It makes little sense for them to join a union representing workers in a place where they do not plan to remain, and even less sense to participate in establishing new union structures. Persuading them to join is costly, and unlikely to return sufficient dues income to make it financially viable. ${ }^{79}$ The most successful strategies we saw in the TWES project depended on well-resourced unions leveraging the industrial strength of their native members (Finland) and pressuring contracts (Netherlands) to enforce extended collective agreements. Individual labor rights violation cases are lengthy and costly to pursue, often requiring the union to provide representation in the posted worker's sending country. The issues are very complex, having to do with the interactions of EU, host country and sending law, as well as local industrial relations practices. Therefore, pursuing court cases cannot be a large-scale solution.

CJEU court decisions have progressively constrained the actions that unions and governments could take to protect posted workers. ${ }^{80}$ Forcing employers to bargain over posted worker conditions is only possible when unions have leverage, and the most significant source of leverage is the strike. However, exercising the right to strike, if done successfully, prevents firms which operate internationally from exercising their right to free movement, because these firms are then unable to move goods or provide services in other member states. If a firm is made less competitive in another EU member state through having a collective agreement imposed through strike action, its free movement rights have been violated. For example, in the Laval decision, the CJEU concluded that

78 Cited in Lisa Berntsen \& Nathan Lillie, Hyper-Mobile Migrant Workers and Dutch Trade Union Representation Strategies at the Eemshaven Construction Sites, ECON. \& Indus. DEMOCRACY (forthcoming 2016).

79 Ian Greer, Zinovijus Ciupjius \& Nathan Lillie, The European Migrant Workers Union and the Barriers to Transnational Industrial Citizenship, 19 EuR. J. INDUs. REL. 52013.

80 Dølvik \& Visser, supra note 9. 
[t]he right of trade unions of a Member State to take . . . collective action [designed to raise the pay and conditions of posted workers above legal minimums] is liable to make it less attractive, or more difficult, for undertakings to provide services in the territory of the host Member State, and therefore constitutes a restriction on the freedom to provide services within the meaning of Article 49 EC. ${ }^{81}$

Although the right to strike is also recognized by the CJEU as a fundamental right, the means used must be "proportionate" to the worker protection goals of the strike. ${ }^{82}$ This proportionality test only goes one way - industrial action can violate a firm's fundamental right to free movement, but a firm through free movement cannot violate a worker's right to strike. ${ }^{83}$ Unions, however, can take industrial action to enforce existing laws, such as minimum wages and extended collective agreements, if national law allows them to do this. In countries where such exist there is a regulatory mechanism to enforce labor standards, albeit dependent on the success of uncertain enforcement action and the willingness of the posted workers to lose their jobs. At best, existing systems are a remedy for some of the workers who are being cheated, but of course most posted workers have neither de facto nor de jure equality with native workers, nor is there a practical possibility for them to have collective voice through organization.

\section{Conclusion}

Market-making in the EU means the removal of barriers to the free movement of workers and services, both geographically and between regulatory regimes, and the intensification of competition - including wage competition. Regulatory regimes, and firms' ability to successfully strategize between them, are a competitive parameter favoring less restrictive and cheaper regulatory environments. The regulation of posting creates windows of opportunity for labor-cost competition by defining posted workers as partially outside the regulatory scope of the receiving country. ${ }^{84}$

81 Case C-341/05, Laval un Partneri Ltd. v. Svenska Byggnadsarbetareförbundet, 2007 E.C.R. I-11767, at 99.

82 Case C-438/05, Int'1 Transp. Workers' Fed'n \& Finnish Seamen's Union v. Viking Line ABP \& Oü Viking Line Eesti, 2007 E.C.R. I-10779.

83 Mitchel Lasser, Fundamentally Flawed: The CJEU's Jurisprudence on Fundamental Rights and Fundamental Freedoms, 15 Theoretical InQuiries L. 229, 251 (2014).

84 Wagner \& Lillie, supra note 11. 
Key to the EU's ideological legitimation of market expansion is the myth that workers can act as effective economic agents in the absence of collective organization or labor market regulation. It is clear from many conversations with posted workers that posted workers cannot realistically be regarded as market players making fully informed decisions about contracts and negotiating on an equal footing with firms. Nor are they always able to enforce contracts when employers decide to abrogate them.

The myth of market consent is an intellectual basis with which the workers' right to have rights is contested. Within the EU this contestation occurs via spaces of partial statelessness, in which regulatory sovereignty is held at bay for mobile workers, because rights become alienable when a person becomes stateless. Collective labor rights cannot be realized if they are alienable; this is a fundamental part of their logic and raison d'être. The trade union maxim "an injury to one is an injury to all" illustrates the point: one worker "selling" his or her labor rights essentially means selling all workers' labor rights, because of the way competitive labor markets work. Insofar as labor rights impose costs on employers, they must be collective and universal in order to be effective, or competitive dynamics will undermine them.

The alienability of labor rights is related to the multilevel nature of the EU polity and the variable regulatory landscape, in which both workers and firms choose among regulatory frameworks. Because of the regulatory variation, workers can only access rights through complex, contingent and uncertain mechanisms, making them alienable in the sense that workers may "choose" to be employed in such a way as to effectively waive their rights. Market power determines to what extent workers realize their rights, or to what extent they "voluntarily" allow their rights to be alienated. There is a contradiction in the promotion of market liberties by the removal of workers' rights; without the power to enforce their contracts through collective action or state regulation, workers lose their ability to conclude and enforce individual contracts. The association of market expansion with personal liberties by EU actors is more appropriately conceived as a form of class domination than market emancipation. 